\title{
The Importance and Position of Ethics in Social Life According to the Islamic Doctrines
}

\author{
Mr. Seyed Ali Razavian \\ Al-Mustafa International University (seminary/Qom/Iran)
}

\begin{abstract}
The position of morality as an instrumental, distinguishing human beings from other creatures, and with the growth and excellence of moral virtues, brings the light of faith to his heart. Obviously, the moral system of Islam is full of ethical virtues and propositions that the Muslim person by their practical implementation, have the ability to complete their religion, and take steps to reform the affairs of the world and the Hereafter. The purpose of the construction of the teachings and doctrines which Islam has made obligatory and believes in them as the foundations of Islam is nothing but proper training for the purpose of institutionalizing the good temper and the healthy and stable social relations that are right and proper in humans. Accordingly, these divine doctrines and commands must always be repeated in order to institutionalize the right ethics. The place and importance of morality in social life is that even the practice of social laws and regulations is not possible without ethics, and morality is the best guarantee of the enforcement of laws and regulations. Hence, ethical debates are among the most important goals of communicating prophets in society, and without it, neither religion will have a conceptual basis for people, nor a society without ethics will be possible. This paper deals with the descriptive analysis approach to the true position of morality from the point of view of the Quran and narrations in society.
\end{abstract}

Keywords: ethics, moral propositions, social relationships, social life 


\section{Introduction}

In the importance and status of good ethics as a human tool that sets man apart from other beings and with the growth and excellence of moral virtues, the light of faith shines through his heart, enough to claim the purpose of building up his teachings and The worship that Islam has enshrined and the belief that they are the foundations of Islam are nothing but good and effective exercises aimed at institutionalizing a good mood and a healthy and lasting social relationship in the proper human being. Understanding the importance of ethics increases the motivation to learn ethical issues in human beings and the more people in society become aware of the importance of ethics in social relationships and the social environment, the more successful they are in pursuing their path of growth and excellence.

Human-beings constantly require to learn all the divine teachings to respond to their divine and divine nature, and in the status quo, the need for ethics and ethical discourses is felt more than ever. It is said that some unknowingly consider ethical issues to be private in the life of a person or consider them to be merely spiritual and spiritual matters and believe that ethical issues only affect the life of the hereafter, while this idea is false. Many ethical issues, rather all of them, affect human life, whether they be material or spiritual. Of course, human society will become a zoo without ethical issues that only cages can prevent the destructive activities of its inhabitants.

With a little reflection on history we find that many societies have been defeated or destroyed in the face of some moral deviation. Also, many rulers have plunged their tribes and people into painful disasters because of their moral weaknesses.

With a little reflection on the history, we discover that many societies have been defeated or destroyed in the face of some moral deviation. Also, many rulers have plunged their tribes and people into painful disasters because of their moral weaknesses. 


\section{The word ethics:}

\subsection{Literal meaning}

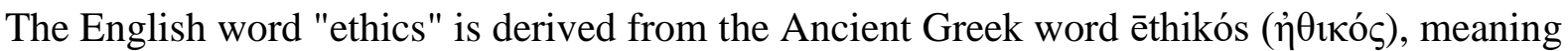
"relating to one's character", which itself comes from the root word êthos ( $\tilde{\eta} \theta 0 \varsigma$ ) meaning "character, moral nature". This word was transferred into Latin as ethica and then into French as éthique, from which it was transferred into English

The Cambridge Dictionary of Philosophy states that the word "ethics" is "commonly used interchangeably with 'morality'. to know some branches of ethics: Intuitive ethics, Normative ethics, Meta-ethics, Descriptive ethics.

\subsection{The idiomatic meaning}

used as the attribute of the action and sometimes as the trait of the action, ie moral work. Ethics in some cases is simply a matter of utilitarian ethics.

Ethics are used in two areas, first: individual identification (good from bad) and second: behavioral practices that are institutionalized within a cultural, religious, social, or philosophical group. Individual ethics are defined or identified by right or wrong goals, motivations, or actions; goals that are learned, created, or developed by individuals in the group.

\section{Man and Society}

The debate between man and society and how humans relate to society has long been debated by scholars, especially by philosophers. Some consider man to be civilized, but others believe that human beings turn to civilization and society only through urgency.

Another group has argued that humanity is not contingent upon civilization, and that humans turn to it for the sake of their logical intellect, while others have argued that human beings tend to be social and civilized. The oldest theory in this respect concerns Plato and Aristotle after him. From Plato's point of view, every human being has to be social because of his own needs and interests. Aristotle, who considered man as a social animal, emphasized that human needs made him social inevitably. Great Islamic scholars such as Farabi, Abu Ali Sina, and scholars of current time have also considered this need to be the reason for the sociality of humans.

From Nahj al-Balagha's point of view, human beings choose social life as being in accordance with their rational nature, and this choice is not due to compulsion or helplessness, but rather to intelligence and understanding. ${ }^{1}$

O' people! Surely no one (even though he may be rich) can do without his kinsmen and their support by hands or tongues. They alone are his support from the rear and can ward off from him his troubles, and they are the most kind to him when tribulations befall him. The good memory of a man that Allah retains among people is better than the property which others inherit from him.

${ }^{1}$ Nahj al-Balagha is the most famous collection of sermons, letters, tafsir and narrations attributed to Ali, cousin and son-in-law of Muhammad pbuh. It was collected by Sharif Razi 
(In the same sermon)

Behold! If anyone of you finds your near ones in want or starvation, he should not desist from helping them with that which will not increase if this help is not extended, nor decrease by thus spending it. Whoever withdraws up his hand from (helping) his kinsmen, he withdraws only one hand, but at the time of his need many hands remain withdrawn up from helping him. Sweet-tempered one can retain the love of his people for good.

According to this sermon, a human being in social life, which is the scene of profit and loss, needs the help of others who draws him to others, and each human being needs compassion and compassion for them because of adversity and hardship.

In sermon 127:

Refrain from scattering and separation that the sole man is the prey of the devil, as the only sheep is the wolf's prey. The expression states the face of human society that people for getting rid of isolation and seclusion also escape the evil gain benefits should be social.

\section{Social Ethics}

Ethics or ethics in the social sciences is a set of values and norms or a list of commonly accepted dos and don'ts and generally accepted beliefs that guide action and behavior in the different territories of life, both individual and social.

In other words, human society needs a set of common principles (visual, value, and material) because of the complex nature of communication.

Social interaction inevitably provides social order and cohesion based on standards and adherence to the accepted normative system.

Some of the principles are formed by customary rules, customs and social habits, some of them by legal norms, and part of them shaped by moral status which is more decisive.

In a broad sense ethical norms are divided into two categories: individual and social norms, although the social sector has a broader range of uses. One of the emerging examples of normative social ethics is recommendation and advice.

According to some sociologists, ethical values by and large, attend to world ethics, and the application of values such as family-oriented values, are nation and humanity. (Georges Gurvitch.121)

Ethics covers virtually all levels of communication and all types and dimensions of action, in other words, there is no realm of outward and inward action and individual and social actions that are left out of the moral norm. Every communication action has a moral component and carries some moral burden. involves moral obligation. (Jeremy Veenstra /68)

As stated earlier, human need for ethics at all levels of social life is undeniable and one of the most powerful and in Steiner's interpretation one of the strongest and most enduring ideological systems in our fixed set of moral beliefs.

In Max Stirner point of view one of the strongest and most enduring belief systems in

Decisive-belief is the moral system.Ethics plays the same role as religion role regarding shaping our identity towards a new personality. There is no doubt that social ethics, as an undeniable necessity, plays very crucial roles and functions at different levels of social 
relations. Ethical precepts, along with other normative precepts, work to harmonize actions and emotions. This coordination is important for peaceful coexistence. everyone benefits from the application of ethics as a system of applied-arguments, it is obvious that in this field, as other fields of social life, the majority of individuals must make a practically adhere to a common ethical system of values and ethics.

furthermore, social ethics reflects the mutual rights and responsibilities of the individual to one another. Some ethical philosophers have argued that ethics is social at least in some sense in expressing social status and the function of ethics in social life and how individuals interact with it. Ethics, such as one's language, originally, or religion, existed before the individual entered or shared more or less, and will continue to exist after the individual. Ethics is an instrument in the hands of society as a principle for the guidance and guidance of smaller individuals and groups.

Ethics is not a purely theoretical field involved in analyzing and explaining good and bad and dos and don'ts, rather a practical, instructional and instructional science that guides people to perform ethical duties and behavioral needs. The most important mission of this field after presenting the guiding norms is to identify and solve objective ethical problems in different areas of social life. (Motahari /110)

\section{The Status and Importance of Ethics in Society}

Understanding the importance of ethics stimulates to learn ethical issues, the more people in society become aware of the importance of ethics in social relationships and the social environment, the more successful they are in reaching the top of growth and prosperity.

constantly it's needed to acquire whole the divine teachings to respond to the Godly-nature, in particular in the present time, the necessity for ethics and ethical discourses is felt more than ever. It is essential to know that some thoughtlessly regard ethical issues as a private matter in one's personal life or consider it to be merely spiritual and spiritual matters and believe that ethical issues only affect the life of the hereafter, while this idea is false. Many ethical issues, rather all of them, have an impact on human life, whether they are material or spiritual. undoubtedly, human society will become such a zoo where only cages can prevent the destructive activities of its inhabitants without human ethics. The position and importance of ethics in social life are such that even social laws and regulations are not possible without the support of ethics and ethics is the best guarantor of the implementation of laws and regulations. Therefore, ethical issues are one of the most important goals of the prophets, and without it, neither religion will be meaningful for the people nor their world will be provided well. A human is worthy of a human name when has a human morality. Otherwise, it is a perilous beast that wreaks through the intellect. If there is no morality, no religion as well, and to harm the individual ethics, the believer's heart gets harmed which is the actual place of religion. that's why, the Prophet (peace and blessings be upon him and his progeny) used to restrain their followers and disciples from wrongdoings and moral vices, and states that preventing is easier than cure by far.

regarding the impact of heinous moral traits the commander of the faithful(Ali ibn Abi Talib) states:

"don't be envious that envy demolishes faith like the fire that burns the firewood. Do not have hostility and hatred with one another that annihilate everything" (186,sermon) 
it suffices to say that In the importance and status of right ethics as a human tool, which sets man apart from other beings, the very purpose of teachings and the worship that Islam has enshrined and the obligatory belief as foundations of Islam are nothing unless effective practices aimed at institutionalizing good mood and a healthy and lasting social relationship in the proper human being. Accordingly, these divine teachings and decrees should be repeated to have stable right mood in the social life of human being.

these daily ritual are similar to exciting regular exercise which brings joy and satisfaction in social life. for example, God the Almighty in the Quran commands us to prayer in order to acquaint man with the truth of prayer which is being far from vice and transgression.

" Indeed the prayer keeps you away from sins and crime.(Quran,29,45)

Therefore, divine teachings and order rituals such as prayer, fasting, pilgrimage, zakat, are all ladder for the human being to reach perfection and purity and each of them can immune humanity from falling into the corruption.To express such moral virtues and delicate points in an ignorant age, far from the Arabian Peninsula civilization, and among the people would live for centuries in hatred, hostility, ignorance, demonstrate God's purpose to escalate a human's disposition.

In one of the moral lectures, Imam Hussein (AS) also assessed some ethical values in order to regulate people's personal and social life.

$O$ 'People spend your life with moral values and hasten to obtain the salvation wealth; don't count good deeds which are received without a rush, obtain admiration through helping others and don't be ashamed by shortening it. Supposing you do a favor for someone who does not appreciate it, never mind, Allah will punish him, and God is the best rewarder and the best bestower.Indeed people's needs are God's blessing towards you hence watch out to not miss them otherwise will be chastised. Verily, goodness is praised and will be compensated. if you saw goodness in a human mold, it would be truly beautiful which attracts everyone. And if you saw the ugliness correctly, you would find it out too ugly and badlooking that every single heart hurts it. $O$ 'people! The one who does charity is noble, and the stingy one is inferior, and the most generous is the one who helps a frustrated person. And the most forgiving is the one who grants amnesty when in power. And the most successful man regarding kindred relation is who communicates with those who are cut off, the roots will sprout again after the branch is cut. Whoever hastens to do a favor for his brother his favor will be returned, and whoever assists his brother for the sake of God, God will reward him when he is in need, He keeps curse away from him. And whoever eliminates the believer's sorrow, God will relieve the sorrow and trouble in the world and the hereafter both. whoever is nice to people, God will be nice to him. Verily God loves a pleasant man. (isa Erbeli,465)

\section{Developing Ethics in Society}

In favor of the ethics in society, not only required to improve our morality but also others in this respect. First of all, one must digest the fact that the material never brings happiness. Although property can provide some prosperity. So would be better to move on to spirituality. It's given this is not an effortless task, but can be achieved by the following tips:

1: Encouragement of Kindness: To be totally appreciated to who has done a favor for you. to talk about it before others. additionally, we had better do the same to others. 
2: Respect and love: to hold elders and man of knowledge in high esteem due to knowledge must be admired not wealth.

3: Rejoicing over the people's success: workaholics should be praised not jealously ruin their dreams. So long as we are satisfied with the success of our community, we can hope that others will behave in the same way toward us and gradually move toward a vibrant society.

4: Giving a hand to destitute: The more assistance to needy, the more increasing the helping trend in society

5: Social Projects: dealing with profitable projects. It is much better done by those who are in power and those who influence people's minds to gradually folks learn about these behaviors and to motivate them to behave appropriately in society.

\section{Conclusion}

Ethics not only plays a great role in saving society and social issues, but it also plays an important role in saving individuals, since ethics is not just about creating a utopia, cultured and development country; to have ethics is required whether to live in a community or lonely. Of course, if there is a society and one wishes to put it aside deliberately, will never succeed in the practice of moral law, because one of the most prominent and uppermost moral duty of man is not to forsake society. the human virtues and merits will be flourished by social exchanging under morality. The human need for morality is just is the same as the need for prophecy and revelation; just as anyone needs revelation, whether living in a society or living individually and no one, in the worldview, ethics, or practices able to be independent thus the initial human being on earth was the prophet who was Adam. it's born out the first man also had needed to know morality and ethics.

for this reason when we refer to Islamic doctrines throughout the Quran and Sunnah, realize all apostles in entire history would encourage people to respect others rights and practice ethics. especially the last holy messenger of God the Prophet (peace be upon him and his immaculate household), He states:indeed I have been dispatched to complete morality and ethics.

to sum it up, Isalm not only provides a scheme for the next world (hereafter) and how to reach salvation and get rid of hell and whatever affiliated to promoting soul in a spiritual way but also teaches us how to behave in the mundane world, which we are all occupied with it, to have a better relationship, to respect humanity, to be nice to people and all nations above from any sects and cast and color are respected. therefor by a glance at Quran one realizes the fact that Islam doctrines are for this world and hereafter both. 


\section{References}

[1] Aristotle, (1955). Nicomachean Ethics.Translated by Thomson, J. A. K. Wiley. Oxford University Press.

[2] Sharif Razi, (1990). Nahj-ul Balāgha. Zawel-qurba. Qom/Iran.

[3] Plato, (1979). Republic. Translated by Larson, Raymond The Republic. Wheeling: Harlan Davidson..

[4] Motahari,(2005). Philosophy of Ethics.Dalil-e ma publisher

[5] Isa Erbeli,(1987).Kashf-ul qoumah fi ul-marifa al-aiimah.Ofoq Beirut

[6] Jeremy Veenstra,(2010).morality and affects. columbia university, ethics journal

[7] Ha Leo Markun,(1925) Max Stirner and the Philosophy of the Individual. HaldemanJulius Company

[8] Georges Gurvitch,(1964), The Spectrum of Social Time. Springer

\section{(Online Sources style)}

[9] http://islamicdoctrines.com/2017/05/07/piety-and-virtue/ 